\title{
Functional System of Private Law Principles
}

\author{
Hurdík Jan \\ Faculty of Law Masaryk University, Czech Republic \\ E-mail address: Jan.Hurdik@law.muni.cz
}

Keywords: Aims of private law regulation; private law principles; a working system of private law principles

\begin{abstract}
The study is a response to: (a) the problem of growing pluralism and disorder of private law principles; (b) the problem of a uniform methodological basis of the formation of a set of private law principles.

The study attempts:

(a) to simplify the methodological approach to principles of private law; (b) to allow a better orientation in the structure of the principles; (c) to arrange the existing private law principles into a functional system. Using a procedurally genetic paradigm and the dialectical method, it aims to formulate a system based on fundamental values originating in the roots of the private law regulation.
\end{abstract}

\section{Defining the problem and the starting points for its solution}

What is crucial to the formulation of private law principles is defining the nature and the objective of the principles and also defining their mode of operation which is dependent on this nature and objective, or in other words, fixing the principles in a broader social context.

These questions can be found to be dealt with in both the legal theory and the judicial practice. Perhaps the most generally accepted approach is that of understanding principles as values or a normative reflection of values, one of the most quoted being the function of principles as orders to optimize something.

But if we try to apply these approaches when organizing a set of private law principles, we run into a feeling of inadequacy or their orientation being out of aim of our attention, which prevents us from answering the questions:

Is there, or can be created, such a system of private law principles which has:

- starting points and fixation of its own,

- goals of its own,

- constants of its own,

- an infrastructure of its own,

- an orderliness of its internal structure,

- a certain form of that orderliness, and, in particular, horizontal or vertical links of individual principles, a mutual relatedness of principles, the possibility of the principles functioning as individual values or in mutually contradictory positions where a functional relationship of ruleexception or balancing is being sought between them?

When solving this problem the author draw on the concept of principles as the value basis of private law whose nature is determined by the objectives of private law as a whole and the basic contradictions that private law is supposed to deal with.

The need to deal with this issue becomes even more pressing due to that. Currently, also in connection with the principles of the developing European private law, the issue of social function, or social dimension, of private law has become the subject of an increasing concern of Europe's leading civil law experts. This dimension can be seen quite clearly in objectives and values on 
which the European principles of private law are being built ${ }^{1}$ (on that in more detail below), and leads us to think about what is to be considered the objective of private law.

Since the beginnings of private law it is justice that has been considered its objective. However, a paradox can be found in its very concept: on the one hand, justice is seen as a universal goal of private law which is pursued by both law and society, and on the other hand, justice takes various forms, and as for its impact on individuals and society even fundamentally different ones. This fact probably led to the embarrassment and reticence with which the concept of justice is accepted by a considerable number of jurists and used in sources of law. When being used, it happens more often in theory than in practice.

A new conception of justice overcomes the choice of "egoism or altruism" replacing it with the term "communication controlled by interests" ${ }^{2}$. All this naturally conceals the original moral content of the concept of justice while considerably reducing the chance of, when trying to achieve justice, interdisciplinarily unifying, developing and applying those values in law that stood at the cradle of the European culture. This gets us closer to the nature of all models of justice which is centered around two basic dimensions on the combination of which virtually every legal system is in fact based, from the extremely totalitarian ones to the ultraliberal ones, namely, the individual and social dimensions. $^{3}$

Individual forms of justice are thus expressions of two fundamental dimensions within which the private law regulation moves. The starting point for the functioning of law is freedom of an individual, existing even before his entering into legal relations and expressing his individual position. The very function of law is to limit the position of an individual in the interests of the society, which is expressed by an approximate equality of positions. Justice is then a synthesis of freedom and equality which defines the balanced position between the individual and social dimensions of private law.

\section{Individual and relational dimensions of private law}

The author draws on the objectives of civil law regulation which includes the definition of a model (normative) solution of the contradiction between the individual and social dimensions of humans in the real world. These dimensions must also find their reflection in the value basis of private law which forms a set of basic principles. Based on these social dimensions of human existence, as early as two hundred years ago a triad of fundamental values was formulated (most notably in the slogan of the French Revolution) which became fundamental human and civil rights and for each dimension of a person in law there is one of them:

- freedom as a modern expression of individuality of a person entering into the society,

- equality as a modern expression of the basic conditions for integration of a person,

- brotherhood as an expression of shared interests and a mutually beneficial coexistence of people.

Each part of the slogan of the French Revolution represented a modified value basis of one generation of human rights.

The first generation of human rights, or legal values, has a distinctly liberal character. It is based on personal freedom and freedom to own property. Equality became the basis of the second generation of human values, and fraternity the foundation of the third generation as the basis of the modern principle of solidarity. ${ }^{4}$

In addition to the dimensions which are normally recognized as being pertained by individual generations of human rights we can see their influence on the structural dimensions of law. While

\footnotetext{
${ }^{1}$ Cf., among others, Principles, Definitions and Model Rules of European Private Law. Draft Common Frame of Reference (DCFR). Interim Outline Edition. Edited by Ch. von Bar, Eric Clive and Hans Schulte-Nölke. Munich: sellier. european law publishers 2008, pp. 12-13

${ }^{2}$ Höffe, O., Gerechtigkeit. 4. Auflage. München: C.H.Beck, 2008, p. 70

${ }^{3}$ Cf. Hurdík, J. - Lavický, P., Systém zásad soukromého práva [A system of private law principles], Brno: MU, 2010, pp. $48-49$

${ }^{4}$ In Micklitz, Hans - W. (editor), The many concepts of social justice in European private law. Cheltenham: Edward Elgar Publishing Limited 2011
} 
emphasizing the principle of freedom is an expression of the individual dimension of law in terms of both its aims and implementation, promoting the principle of equality introduces into law a relational dimension which is then lifted onto a qualitatively higher level ${ }^{5}$ by the principle of brotherhood (fraternité, Brüderlichkeit), i.e. in the current terminology, by the principle of solidarity.

However, the core values on which private law is being built do not arise simultaneously but has been undergoing a process of mutual derivation: freedom is primary, limited then (phenomenally) by equality in order to work jointly towards an equitable (fair) balance.

Freedom is then the starting point, equality being derived from it. It is not a simple derivative, though, achievable by simple logical reasoning. One has to become aware of the position of law and its function in relation to an individual and the society. The role of law is to correct people's conduct. This means that law enters into a certain state of the society which it must perceive as a whole but to protect only in that part that requires protection and to regulate only to the extent necessary in relationships that are beyond the extra-legal dimensions and extra-legal regulatory systems affecting the state of society. In this sense, the individual position is pre-legal and it is only the social position that becomes a legal one. Law regulates social relations and is not interested in individuals outside the society.

The relationship of freedom and equality is not logical but axiomatic. ${ }^{6}$ This relationship, too, must be accepted in its historical (phylogenetical) form. Freedom has been generally accepted as a fundamental value of human society only since the beginnings of modernity and within the dimensions of modernity it was gradually brought into life. The system presented by us is historically conditioned and can only be applied at the level of the modern, or postmodern, society. This structure of human rights is reflected in the pattern of private law regulation: all (private) law regulation is a minimum restriction of freedom of people and citizens. This means that between freedom, or other principles that promote the principle of freedom, and the principles representing the values on the basis of which freedom is (legally) restricted there is not a horizontal relationship, but the principle of freedom with its group has an apriori position in relation to the principles restricting freedom. No matter how much this relationship is blurred in the dimensions of private law regulation it keeps to be - potentially or actually - present.

A substantial part of the principles of private law follows this pattern when it belongs to one of two groups: those that support freedom and those limiting it, though often very indirectly through various legal techniques.

This hierarchical construction of private law principles is manifested not only at the level of private law as a relatively coherent system but, within its context, at lower system levels: the right to ownership is based on freedom of ownership, followed by its restrictions which correspond to the respective principles (e.g. the prohibition of abuse of ownership ), contract law is based on contractual freedom added to by restrictive principles, or rules (e.g. pacta sunt servanda), and, in the end, responsibility is also based on freedom of a person's actions which is limited by responsibility restrictions based on sub-ordinated principles (e.g. neminem leadere and casum sentit dominus).

\section{The pillars of the value basis of private paw}

However, if private law is to have a rigorously constructed system of values and institutions then its value basis - statically understood - is based on three pillars:

1) freedom,

2) and equality (with tendency towards solidarity), these two pillars being an antipode which is moderated by

3) adequacy which is a tool for balancing the degree of interventions in the freedom of people and the scope of application of the principle of equality (of opportunities, weapons or goals).

\footnotetext{
${ }^{5}$ Characterized, in particular, by the presence of values such as humanity or altruism.

${ }^{6}$ Knapp, V., Co je dovoleno a co zakázáno [What is allowed and what is banned], Právník, č. 1, 1990, p. 14.
} 
These pillars are not coordinate: they have - in terms of the considerations mentioned above - a hierarchical arrangement resulting from the hierarchy of the entire legal system, including the legal principles.

In terms of our methodology the following view emerges:

1) The individual dimension of a person and his legal potential is based on the principle of freedom (in terms of the dialectical method it is a thesis);

2) the relational dimension is based on the principle of equality (antithesis) and

3) leads to equity, justice, etc. (synthesis).

The relationship is therefore genetically primarily conditioned by the principle of freedom, secondarily by the principle of equality, and being limited it is subject to equity.

One cannot overlook a feedback, though, through which the relational dimension affects and limits freedom.

The result is a dialectical interaction of both dimensions on which the (private) legal regulation is being built.

In this sense it is not a conflict of principles as a whole. As admitted also by F. Bydlinski, ${ }^{7}$ what matters is the degree and scope of restrictions in which it is possible achieve implementation of the principle that interferes with a "primary" or "higher" one; if an "exception" to the principle of freedom is applied, freedom then occupies all of the remaining space which was not affected by the "exception". Put simply, the solution of the conflict between the values associated with freedom against the values connected with equality, or against the values associated with equity (balance, justice) is not balancing interests but using the rules of specialty and subsidiarity, i.e. according to the rule of specification.

To a large extent, this solves the dilemma that occurs when the relational dimension is built on a mere formal confrontation with the individual dimension, and into the bargain, at the same (horizontal) level. This gives rise to a conflict, which is difficult to solve, between two principles (i.e. those of liberty and equality) with consequences that accompany the continental legal regulation throughout the period of modernity and whose manifestation is to heal this injury with patches of equity, prohibition of abuse, morals, etc.; and what is more, in keeping with the Roman Pretorian law to keep considering equity as an element foreign to the system of legal rules which applies to the process of applying formal legal rules ex post, as a result of finding a conflict between a formal legal solution and a fair one. It should be pointed out, though, that this system leaves for the existing solution (the so-called test of proportionality of objectives and means, i.e. balancing of principles in collision (Dworkin)) those principles that are in this gradually built system on the same level (e.g. more principles supporting freedom).

The paradox mentioned in the introduction to this chapter lies in the dialectical nature of the principles when put against their own legal orders:

- legal orders as systems of "standard" rules of law are, on the one hand, imbued with values expressed by legal principles, on the other hand, they are in a conflict with them;

- legal orders as systems of "standard" legal rules contain principles or references explicitly formulated by the legislature, while other principles are created outside the legislative process during the implementation and application of law,

- legal systems as systems of "standard" legal rules evolve in confrontation with the development and application of a certain system of values: in one social situation the principles are a conserving element of the development while the set of standard rules of law accelerating one, in another situation it is vice versa.

\section{The form of a working value system of private law}

Summing up the above mentioned theses, we may see a gradual, vertically organized value system of private law, consisting of three sets formed around the basic functional principles: liberty, equality, equity.

\footnotetext{
${ }^{7}$ Bydlinski, F. Grundzüge der juristischen Methodenlehre. Wien: FOWI 2003, p. 46.
} 
Freedom is a primary, pre-legal, and apriori expression of human individuality. For a long time, especially in the standard democracies from where this concept also spread to the countries of Central and Eastern Europe after the fall of the Iron Curtain, freedom has been regarded an axiom, or an untouchable and often the only default, principle destitute of any opposition. However, freedom is at the same time an expression of favoring an individual over other individuals, or over the society, and in the society it cannot stand without restrictions.

Equality is an expression of the social dimension of man and the starting factor of the space which man occupies between the individual and social counterparts of his existence.

Equity in this context is a complementary element of freedom and equality which defines the position of balance between individual and social, between liberty and equality [see also the reasoning in e) of this part]. Its role is to seek and achieve a synthesis of contradictions between the individual and the relational starting points of legal relationships which themselves are expressed most generally as principles. Equity in this sense is a general principle at the level of freedom and equality.

This constitutes the basis for building a three-level system of private law principles:

1. freedom as a primary principle, a thesis and an individual value basis,

2. equality as a secondary principle, an antithesis and a social antipode of the basis,

3. equity as a tertiary principle, as a way towards a synthesis of the two positions.

Each of these three principles represents, for its function in the system of private law values, the leading principle accompanied by a group of others that support the function of the respective leading principle. Thus, on the basis of the above mentioned considerations, a set of principles may be created that expresses an axiological basis of regulation of the relationship of persons of private law put into the following genetically and functionally constructed system:

External (non-legal) principles: The underlying principle Freedom

Equality

Equity

\author{
The associated principles \\ Individual autonomy (autonomy of will) \\ Everything which is not forbidden is allowed \\ Dispositiveness \\ Vigilantibus iura
}

Equal opportunities

Prohibition of discrimination

Protection of the weaker party in a relationship Adequacy (the degree which is appropriate to the
situation)
Good manners (Good Faith and Fair Dealing in
European law
Prohibition of abuse
Democracy
Reasonability

Applying the above mentioned principles in their functionally genetic algorithm aims to achieve the objective of private law regulation, i.e., put most generally, to achieve a balance of the interests involved. This objective is often equated with achieving justice in terms of values.

Achieving a justice that is defined in this manner, however, would fail its purpose if it did not have an additional characteristic:

a) the main goal and purpose of applying private law regulation based on promotion of general human, external, non-legal values of interpersonal relationships, i.e. achieving justice, is added to by the principles if it were not associated with achieving practical goals pursued by the person who seeks justice, and at the same time 
b) if it were not predictable and if it were not based on standardized starting points and procedures for achieving justice.

Additional principles representing the intrinsic values of techniques of legal regulation that we call internal principles:

\section{The underlying principle}

$\underline{\text { Effectiveness }}$

Security

\section{The associated principles}

Priority of economic considerations (liberalism, economic analysis of law...)

Teleological interpretation

Prohibition of avoiding the law in contradiction with its purpose

Protection of good faith (in the psychological sense)

Prohibition of (real) retroactivity

Protection of acquired rights

Legitimate expectations

Transparency

Protecting the rights of third parties

Prevention

\section{Conclusions}

The author attempts to answer the question if it is possible to formulate a clear and working set of private law principles from a number of starting points the most important of which are:

- changes in the general methodology of science and its paradigms

- an increased interest of legal theorists and practitioners to find goals of private law regulation

- an increased interest of legal theorists and practitioners to formulate a set of private law principles and their functional integration into the system of private law regulation

- applying the procedural-genetic paradigm and dialectical method.

The most important theoretical and methodological step seen by the author is to define the system of private law as a whole which could also be applied to creating a system of its principles as an integral part of private law.

This basis can be found in the dialectical relationship between the two fundamental dimensions that are the essence of legal regulation. If the essence of the legal regulation is the modeling of relationships between man and society, then legal regulation has two main dimensions: individual and relational. With them are connected two dialectical values, or goals whose addressee is man after all as the alpha and omega of legal regulation, but each of which procedurally-genetically belongs to one of the above mentioned dimensions: freedom is an individual dimension attribute and equality is a social dimension attribute.

The above mentioned dimensions are, in the process of legal regulation, confronted with each other and the goal is finding a balance of the involved values and interests. In the process of legal regulation, though, the individual dimensions do not have a horizontal position. Procedurallygenetically, the primary position is occupied by freedom which is confronted with equality as a vector (an approximate one) of the social dimension for the outcome of this confrontation to be justice (equity) as the key objective of private law regulation.

On this basis, the author presents a functional system of private law principles which, based on the previous conclusions, consists of the basic (primary) principles of private law which may be complemented with partial principles that synergistically operate with the respective primary principle and are its expression. 


\section{References}

[1] Alpa, G., a kol, Interpretazione giuridica e analisi economica, Milano: Guiffré, 1982

[2] Bárány, E., (Ne)spravodlivost' práva v postmodernej situácii [(In)justice of law in the postmodern situation], Právny obzor, č. 5-6, 2002, pp. 412-427

[3] Batiffol, H., Le déclin du droit. Examen critique, Archives de philosophie du droit, sv. VIII, Sirey, 1963, p. 43n.

[4] Bell, D., The Coming of Post-Industrial Society, New York, 1973

[5] Block, W., L'économie politique selon les libertariens. Journal des économistes et des études humaines, Mars 1995

[6] Bydlinski, F. Grundzüge der juristischen Methodenlehre. Wien: FOWI 2003

[7] Carbonnier, J., Flexible droit, 8. édition, Paris: L.G.D.J., 1995

[8] Coulanges, P., L'analyse économique de la production de droit, Aix-en-Provence, 1991

[9] David, R., Les diverses conceptions de 1'ordre social et du droit. In: Le droit comparé: droits d'hier, droits de demain, Economica, 1982

[10] Davis, S. M.,- Meier, Ch., Blur. The Speed of Change in the Connected Economy, Oxford, 1998

[11] Denninger, K., Rechtsperson und Solidarität, Frankfurt am M., 1967

[12] Duguit, L., Les transformations générales du droit privé depuis le Code Napoléon, Paris, 1912

[13] Eliáš, K. (editor), Soukromé právo v pohybu [Private law in motion]. Plzeň: Vydavatelství a nakladatelství Aleš Čeněk, s.r.o., 2005

[14] Eliáš, K.-Zuklínová, M., Principy a východiska nového kodexu občanského práva [Principles and bases of the new Code of Civil Law], Linde Praha, a.s., 2001

[15] Feyerabend, P., Der wissenschaftliche Realismus und die Autorität der Wissenschaften, Ausgewählte Schriften, Braunschweig-Wiesbaden, 1978

[16] Ferry, L., Philosophie politique, Tome 1 and 2, Paris, 1984

[17] Fukuyama, F., Trust: The Social Virtues and the Creation of Prosperity, New York-Londýn: Free Press

[18] Gaillard, E., Le pouvoir en droit privé, Economica, 1985

[19] Gray, J., Marné iluze. Falešné představy globálního kapitalismu [False Dawn: The Delusions of Global Capitalism], I. vydání, Košice: PARADIGMA.SK

[20] Hart, H. L. A., Rawls, on Liberty and its Priority. University of Chicago Law Review 40, Printemps, 1973

[21] Hegel, G.W.F., Principes de philosophie du droit, Volume I

[22] Henry, J.-P., Vers la fin de l'état et de droit?, Revue du droit public, 1977, p. 1207 n.

[23] Hurdík, J., Principiální hodnoty a institucionální pilíře (soukromého) práva v dynamice vývoje společnosti/Die Grundwerte und die institutionellen Pfeiler (des Privatrechts) in der Entwicklung der Gesellschaft. In: Blaho, P.-Švidroň, J. (ed.), Kodifikácia, europeizácia a harmonizácia skromného práva/Kodifikation, Europäisierung udn Harmonisierung des Privatrechtes, Bratislava: IURA EDITION, 2005, pp.323-350

[24] Hurdík, J., Teze o individuálních a sociálních dimenzích práva a osoby v právním smyslu [Theses about individual and social dimensions of law and persons in the legal sense], Právník, č.7, 2002, pp.797-804 
[25] Hurdík, J. - Lavický, P., Systém zásad soukromého práva [A system of private law principles], Brno: MU, 2010

[26] Chastaing, M., Descartes, introducteur a la vie personnelle, Esprit, juillet 1937, pp. 531-547

[27] Ihering, R., von, Geist des römischen Rechts auf den verschiedenen Stufen seiner Entwicklung, Tome III., Leipzig, 1869

[28] Knoll, Von den drei Wesenstheorien der Gesellschaft, Individualismus, Totalismus, Personalismus, Wien, 1949

[29] Laurent, F., Principes de droit civil, Tome I., Éd.. Bruylant, Brusel, 1869

[30] MacPherson, C., Democratic Theory. Essays in Retrieval, Oxford, 1973

[31] Mauss, M., Sociologie et Anthropologie, 5. édition, Paris, 1980

[32] Maziére, P., Le principe d'égalité en droit privé, Presses universitaires d'Aix - Marseille, 2003

[33] Oppetit, B., Droit et modernité, PUF, Paris, 1998

[34] Rawls, J., A Theory of Justice, 5th edition, Cambridge, Massachusetts: Harvard University Press, 1973

[35] Rifkin, J., Acces. Das Verschwinden des Eigentums. Warum wir weniger besitzen und mehr ausgeben werden, Fischer Taschenbuch Verlag, Frankfurt am M., 2002

[36] Ripert, G., Le déclin du droit. Études sur la législation contemporaine, Paris: L.G.D.J., 1949

[37] Savigny, F. C. von, System des heutigen römischen Rechts, Tome II., Berlin, 1840

[38] Sen, A., Éthique et économie, 2. édition, Paris: Preses universitaires de France, 1993

[39] Sen, A., Un nouveau modèle économique. Développement, justice, liberté, Paris: Éditions Odile Jakob, 2003

[40] Smith, A., AN INQUIRY into the Nature and Causes of the Wealth of Nation, Tome 1, London: editor Dwin cannon, 1961

[41] Stammler, R., Rechtsphilosophische Abhandlungen und Vorträge, sv. I., 1925

[42] Valentin, V., Les conceptions néo-libérales du droit, Paris: Vyd. Economica, 2002 